\title{
KEEFEKTIFAN STRATEGI OK5R (OVERVIEW, KEY IDEALS, READ, RECORD, RECITE, REVIEW DAN REFLECT) DALAM PEMBELAJARAN MENULIS PARAGRAF EKSPOSISI PADA SISWA KELAS IX SMP NEGERI 42 BULUKUMBA
}

\author{
Andi Paida \\ Fakultas Keguruan dan Ilmu Pendidikan, Universitas Muhammadiyah Makassar \\ Jl. Sultan Alauddin No. 259, Makassar \\ Email: andipaidahadli@gmail.com
}

\begin{abstract}
Effectiveness Strategy OK5R (Overview, Key Ideals, Read, Record, Recite, Review and Reflect) in Paragraph Writing Learning Exposition in Class IX SMPN 42 Bulukumba. This study aims to determine the effectiveness of the strategy OK5R (Overview, Key Ideals, Read, Record, Recite, Review, and Reflect) in Paragraph Writing Learning Exposition in Class IX SMPN 42 Bulukumba. The population in this study consisted of two classes totaling 58 students. Through random sampling techniques and gained 48 students, ie 24 out of the class IXB as an experimental class and 24 students of the class IXa as the control class. The data collection is done by administering a pretest and posttest. Descriptive analysis showed that the average value of student learning outcomes with the experimental class OK5R Strategies (Overview, Key Ideals, Read, Record, Recite, Review, and Reflect) was 68.3 pretest and posttest 81 , compared with the control class average value average student learning outcomes pretest posttest 68.3 and 75.4. Based on the results of inferential statistical hypothesis test obtained by using the value of $\sigma$ $(0.05)$, the $\mathrm{H} 1$ is accepted so that it can be concluded that the presence of OK5R Strategies (Overview, Key Ideals, Read, Record, Recite, Review, and Reflect) then learning will be effective.
\end{abstract}

\begin{abstract}
Abstrak: Keefektifan Strategi OK5R (Overview, Key Ideals, Read, Record, Recite, Review dan Reflect) dalam Pembelajaran Menulis Paragraf Eksposisi pada Siswa Kelas IX SMP Negeri 42 Bulukumba. Penelitian ini bertujuan mengetahui Keefektifan Strategi OK5R (Overview, Key Ideals, Read, Record, Recite, Review, dan Reflect) dalam Pembelajaran Menulis Paragraf Eksposisi pada Siswa Kelas IX SMP Negeri 42 Bulukumba. Populasi dalam penelitian ini terdiri dari 2 kelas berjumlah 58 siswa. Pengambilan sampel melalui teknik acak dan diperoleh 48 siswa, yaitu 24 dari kelas IXb sebagai kelas eksperimen dan 24 siswa dari kelas IXa sebagai kelas kontrol. Pengumpulan data dilakukan dengan pemberian pretest dan posttest. Hasil analisis deskriptif menunjukkan, nilai rata-rata hasil belajar siswa kelas eksperimen dengan Strategi OK5R (Overview, Key Ideals, Read, Record, Recite, Review, dan Reflect) adalah Pretest 68,3 dan posttest 81 , dibanding kelas kontrol dengan nilai rata-rata hasil belajar siswa pretest 68,3 dan posttest 75,4 . Berdasarkan hasil statistik inferensial dengan menggunakan uji hipotesis diperoleh nilai $\sigma(0,05)$, maka H1 diterima sehingga dapat disimpulkan bahwa dengan adanya Strategi OK5R (Overview, Key Ideals, Read, Record, Recite, Review, dan Reflect) maka pembelajaran akan efektif.
\end{abstract}

Kata Kunci: Keterampilan menulis ,Strategi OK5R

Menulis merupakan kegiatan yang membutuhkan beberapa keterampilan yang cukup kompleks dan sulit. Menulis membutuhkan sejumlah pengetahuan dan keterampilan seperti pemilihan kata, gaya bahasa, hubungan antarparagraf, dan keterampilan dalam menyu- sun kalimat sesuai dengan maksud yang ingin disampaikan kepada pembaca.

Salah satu strategi pembelajaran yang dapat diterapkan dalam upaya meningkatkan hasil belajar siswa adalah strategi OK5R (Overview, Key Ideals, Read, Record, Recite, 
Review, dan Reflect) artinya, Menyelidiki, Ideide kunci, Membaca, Mencatat, Mendaras, Mengulangi, Merenungkan) melalui pengajaran dan pemodelan guru untuk meningkatkan penampilan siswa terhadap materi pelajaran.

Strategi OK5R sebagai pendekatan konstruktif, yakni pengetahuan dibangun (dikonstruksi) manusia sedikit demi sedikit yang diberi makna melalui pengalaman nyata dan hasilnya diperluas melalui konteks yang terbatas dan tidak sekonyong-konyong. Pengetahuan bukanlah seperangkat fakta, konsep, atau kaidah yang siap untuk diambil dan diingat.

Menulis merupakan salah satu kemampuan berbahasa. Dalam pembagian kemampuan berbahasa, menulis selalu diletakkan paling akhir setelah kemampuan menyimak, berbicara, dan membaca. Meskipun selalu ditulis paling akhir, bukan berarti menulis merupakan kemampuan yang tidak penting. Dalam menulis semua unsur keterampilan berbahasa harus dikonsentrasikan secara penuh agar mendapatkan hasil yang benar-benar baik. Henry Guntur Tarigan (1986: 15) menyatakan bahwa menulis dapat diartikan ebagai kegiatan menuangkan ide/ gagasan dengan menggunakan bahasa tulis sebagai media penyampain.

Menurut Djago Tarigan dalam Elina Syarif, Zulkarnaini, Sumarno (2009) menulis berarti mengekpresikan secara tertulis gagasan, ide, pendapat, atau pikiran dan perasaan. Kata "paragraf" berasal dari bahasa Yunani yang terdiri atas dua kata, "para" yang berarti "di samping" dan "graphein" yang berarti "menulis".

Pada waktu dahulu paragraf disimbolkan dengan tanda, yang berdiri pada permulaan margin suatu manuscript di samping suatu teks. Sekarang tanda yang digunakan untuk menunjukkan awal paragraf bukan tanda seperti di atas lagi, melainkan berupa takukan. Paragraf merupakan suatu kesatuan pikiran yang biasanya terdiri atas sekelompok kalimat yang saling berhubungan (walaupun adakalanya tidak lebih dari satu kalimat) pada karangan tertulis. Jadi, paragraf merupakan suatu kesatuan pikiran yang biasanya terdiri atas kelompok kalimat yang saling berhubungan (walaupun adakalanya tidak lebih dari satu kalimat (Ambo Enre dalam Fauziah( 2008: 14).

Paragraf-paragraf yang membangun satu tulisan dilihat dari segi sifat dan wujudnya dibagi atas: (a) Paragraf Pembuka (b) Paragraf Penghubung (c) Paragraf Penutup. Syafi'ie dalam Munirah (2007: 2), menyatakan bahwa eksposisi adalah wacana berusaha atau menjelaskan pokok pikiran yang dapat memperluas pengetahuan penulis. Paragraf ini bertujuan menyampaikan fakta-fakta secara teratur, logis, dan saling bertautan dengan maksud untuk menjelaskan suatu ide, istilah, masalah, proses, unsur-unsur sesuatu, hubungan sebab-akibat, dan sebagainya.

Gorys Keraf (dalam Kusnadi dkk, 2009: 34 - 35) menyatakan bahwa Eksposisi/ penjelasan adalah bentuk tulisan atau retorika yang berusaha untuk menerangkan atau menguraikan suatu pokok pikiran yang dapat memperluas pengetahuan seseorang.

\section{METODE}

Jenis penelitian ini adalah quasi experiment dengan desain penelitian yang digunakan adalah Pretest-Posttest Group Design. Adapun variabel penelitian ini terbagi menjadi dua, yaitu: Variabel $\mathrm{X}$, pembelajaran membaca paragraf eksposisi dengan menggunakan straregi OK5R (Overview, Key Ideals, Read, Recocd, Recite, Review dan Reflect) Variabel Y, hasil pembelajaran efektif menulis paragraf eksposisi dengan menggunakan straregi OK5R (Overview, Key Ideals, Read, Recocd, Recite, Review dan Reflect) tanpa menggunakan straregi OK5R (Overview, Key Ideals, Read, Recocd, Recite, Review dan Reflect) siswa Kelas IX SMP Negeri 42 Bulukumba.

Tabel 1. Model Desain Penelitian

\begin{tabular}{|l|l|l|l|}
\hline Kelompok & Pretest & Perlakuan & Posttest \\
\hline Eksperimen & X1 & T1 & X2 \\
Kontrol & Y1 & - & Y2 \\
\hline
\end{tabular}

Keterangan:

$\mathrm{X} 1, \mathrm{Y} 1$ : pretest

T1 : Perlakuan di kelas eksperimen

$\mathrm{X} 2, \mathrm{Y} 2$ : Posttest

Pembelajaran dengan menggunakan strategi OK5R adalah cara efektif yang digunakan siswa untuk memperoleh kesempatan lebih banyak dalam memanfaatkan pengetahuan. Populasi penelitian ini adalah siswa kelas IXa dan siswa kelas IXb SMP Negeri 42 Bulukumba yang berjumlah 58 siswa yang tebagi ke dalam dua kelompok, yaitu kelas IXa dan IXb. 
Tabel 2. Keadaan Populasi Siswa SMP Negeri 42 Makassar

\begin{tabular}{|c|c|c|c|c|}
\hline No. & Kelas & \multicolumn{2}{|c|}{ Jumlah } & \multirow{2}{*}{ Total } \\
\cline { 3 - 4 } & & $\begin{array}{c}\text { Laki- } \\
\text { laki }\end{array}$ & Perempuan & \\
\hline 1. & IXa & 15 & 15 & 30 \\
\hline 2. & IXb & 15 & 13 & 28 \\
\hline \multicolumn{2}{|c|}{ Jumlah } & 30 & 28 & 58 Siswa \\
\hline
\end{tabular}

Sampel adalah wakil yang dipilih dari populasi dan dijadikan subjek penelitian. Penarikan sampel dalam penelitian ini menggunakan teknik purpose random sampling, artinya penentuan sampel dilakukan sengaja dengan jumlah yang representatif pada kelas penelitian. Sampel penelitian ditetapkan kelas IXa yang berjumlah 30 orang sebagai kelas kontrol dan kelas IXb yang berjumlah 28 orang sebagai kelas eksperimen. Data yang diperoleh dari sampel melalui instrumen tes yang dipilih akan digunakan untuk menjawab pertanyaan penelitian atau menguji hipotesis yang diajukan peneliti. Oleh karena itu, data perlu diolah dan dianalisis agar memunyai makna guna pemecahan masalah tersebut. Pengolahan data hasil belajar dalam penelitian ini digunakan teknik analisis statistik deskriptif dan statistik inferensial.

\section{HASIL DAN PEMBAHASAN}

Pada bagian ini diuraikan data penelitian Strategi OK5R (Overview, Key Ideals, Read, Record, Recite, Review, dan Reflect) dalam pembelajaran menulis paragraf eksposisi pada siswa kelas IX SMP Negeri 42 Bulukumba yang menggunakan jenis penelitian quasi eksperimen. Adapun nilai siswa kelas eksperimen dan kelas kontrol yang diperoleh berdasarkan hasil analisis data, penelitian yang diolah dan dianalisis dengan menggunakan program komputer Statistical Product Service Solusion (SPSS) versi 21 windows yang diuraikan secara terpisah.

\section{Data Hasil Belajar Sebelum Perlakuan}

Data hasil belajar siswa kelas eksperimen dan kelas kontrol:
Dari hasil data yang diperoleh siswa sebelum perlakuan dapat diuraikan bahwa nilai kelas eksperimen dan kelas kontrol adalah sebagai berikut, nilai siswa kelas eksperimen yang mendapatkan nilai 55 sebanyak 5 orang, yang mendapatkan nilai 60 sebanyak 3 orang yang mendapatkan nilai 65 sebanyak 2 orang, yang mendapatkan nilai 70 sebanyak 5 orang, yang mendapatkan nilai 75 sebanyak 5 orang, yang mendapatkan nilai 80 sebanyak 2 orang dan yang mendapatkan nilai 85 sebanyak 2 orang. Jadi, nilai rata-rata siswa kelas eksperimen sebelum perlakuan adalah 68 .

Nilai siswa kelas kontrol yang mendapatkan nilai 55 sebanyak 5 orang, yang mendapatkan nilai 60 sebanyak 4 orang, yang mendapatkan nilai 65 sebanyak 3 orang, yang mendapatkan nilai 70 sebanyak 5 orang, yang mendapatkan ni-lai 75 sebanyak 4 orang, dan yang mendapatkan nilai 80 sebanyak 3 orang. Jadi, nilai rata-rata siswa kelas kontrol sebelum perlakuan adalah 66,7 .

\section{Data Hasil Belajar Siswa Setelah Perlakuan}

Data Hasil Belajar Siswa Kelas Eksperimen dan Kelas Kontrol:

Hasil data yang diperoleh siswa setelah perlakuan dapat diuraikan bahwa nilai kelas eksperimen dan kelas kontrol adalah sebagai berikut nilai siswa kelas eksperimen yang mendapatkan nilai 75 sebanyak 9 orang, yang mendapatkan nilai 80 sebanyak 6 orang, yang mendapatkan nilai 85 sebanyak 4 orang, dan yang mendapatkan nilai 90 sebanyak 5 orang. Jadi, nilai rata-rata siswa kelas eksperimen setelah perlakuan adalah 81 .

Nilai siswa kelas kontrol yang mendapatkan nilai 70 sebanyak 10 orang, yang mendapatkan nilai 75 sebanyak 6 orang, yang mendapatkan nilai 80 sebanyak 4 orang, dan yang mendapatkan nilai 85 sebanyak 4 orang. Jadi, nilai rata-rata siswa kelas kontrol setelah perlauan adalah 75,4 .

Pengujian Persyaratan Analisis

Uji Normalitas

Pretest kelas eksperimen dan kelas kontrol 
Tabel 3. Uji Normalitas pada Tes Awal (Pretest) Kelas Eksperimen dan Kelas Kontrol SMP Negeri 42 Bulukumba

Tests of Normality

\begin{tabular}{|l|r|r|r|r|r|r|}
\hline & \multicolumn{4}{|c|}{ Kolmogorov-Smirnov $^{\mathrm{a}}$} & \multicolumn{3}{c|}{ Shapiro-Wilk } \\
\cline { 2 - 7 } & \multicolumn{1}{|c|}{ Statistic } & Df & \multicolumn{1}{c|}{ Sig. } & \multicolumn{1}{c|}{ Statistic } & Df & Sig. \\
\hline Pretest_Eks &, 151 & 24 &, 164 &, 920 & 24 &, 059 \\
Pretest_Kon &, 154 & 24 &, 147 &, 908 & 24 &, 031 \\
\hline
\end{tabular}

Lilliefors Significance Correction

Jika nilai signifikan pada table Shapiro-Wilk $\geq$ $\alpha=0,05$ maka data berdistribusi normal. Jika nilai signifikan pada table Shapiro-Wilk < $\alpha=0,05$ maka data tidak berdistribusi normal.
Karena signifikan pada tabel Shapiro-Wilk = $0,000 \geq \alpha=0,05$ maka data tersebut berdistribusi normal.

Posttest kelas eksperimen dan kelas kontrol

Tabel 3 Uji Normalitas Pada Tes Akhir (Posttest) Kelas Eksperimen dan Kelas Kontrol SMP Negeri 42 Bulukumba.

Tests of Normality

\begin{tabular}{|l|r|r|r|r|r|r|}
\hline & \multicolumn{4}{|c|}{ Kolmogorov-Smirnov $^{\mathrm{a}}$} & \multicolumn{3}{c|}{ Shapiro-Wilk } \\
\cline { 2 - 7 } & Statistic & Df & \multicolumn{1}{c|}{ Sig. } & Statistic & Df & Sig. \\
\hline Posttest_Eks &, 222 & 24 &, 003 &, 825 & 24 &, 001 \\
Posttest_Kon &, 246 & 24 &, 001 &, 815 & 24 &, 001 \\
\hline
\end{tabular}

\section{Lilliefors Significance Correction}

HO : berdistribusi normal

H1 : tidak berdistribusi normal

Jika nilai signifikan pada table Shapiro-Wilk $\geq$ $\alpha=0,05$ maka data berdistribusi normal Jika nilai signifikan pada table Shapiro-Wilk $<\alpha=0,05$ maka data tidak berdistribusi normal. Karena signifikan pada tabel Shapiro-Wilk $=0,001<$ $\alpha=0,05$ maka data tersebut tidak berdistribusi normal,ini terjadi pada kelas kontrol. Sedangkan pada kelas eksperimen signifikan pada table Shapiro-Wilk $=0,001 \leq \alpha=0,05$ maka data tersebut tidak berdistribusi normal.

Uji Homogenitas

Tabel 4 Uji Homogenitas Kontrol SMP Negeri 42 BulukumbaPada Tes Awal Kelas Eksperimen dan Kelas kontrol

Test of Homogeneity of Variances

Nilai Analisis Data Analisi Data

\begin{tabular}{|c|c|c|c|}
\hline Levene Statistic & df1 & df2 & Sig. \\
\hline ,279 & 1 & 46 &, 600 \\
\hline
\end{tabular}


Peningkatan Nilai Pretest, Posttest Kelas Eksperimen

Pada tabel di bawah akan diuraikan secara jelas mengenai peningkatan nilai hasil belajar siswa SMP Negeri 42 Bulukumba

Tabel 5 Kategori, Frekuensi dan Presentase Hasil Pretest (Tes Awal) Siswa Kelas IX Eksperimen SMP Negeri 42 Bulukumba

\begin{tabular}{|c|c|c|c|}
\hline Interval & Kategori & Frekuensi & Persentase \\
\hline $90-100$ & $\begin{array}{c}\text { Sangat } \\
\text { tinggi }\end{array}$ & 0 & 0 \\
\hline $80-89$ & Tinggi & 4 & 16,6 \\
\hline $70-79$ & Sedang & 10 & 41,7 \\
\hline $40-69$ & Rendah & 10 & 41,7 \\
\hline $0-39$ & $\begin{array}{c}\text { Sangat } \\
\text { Rendah }\end{array}$ & 0 & 0 \\
\hline & Jumlah & 24 & 100 \\
\hline
\end{tabular}

Dari Tabel 5 di atas menunjukkan hasil pretest siswa kelas eksperimen, tidak ada siswa yang berada pada klasifikasi sangat tinggi skor 90100. Hasil evaluasi siswa pada saat pretest berada pada skor tinggi yang diperoleh 4 siswa $(16,6 \%)$ dan klasifikasi sedang diperoleh 10 siswa $(41,7 \%)$ serta klasifikasi rendah diperoleh 10 siswa $(41,7 \%)$.

Tabel 6 Kategori, Frekuensi dan Presentase Hasil Posttest (Tes Akhir) Siswa KelasIXEksperimen SMP Negeri 42 Bulukumba

\begin{tabular}{|c|c|c|c|}
\hline Interval & Kategori & Frekuensi & Persentase \\
\hline $90-100$ & $\begin{array}{c}\text { Sangat } \\
\text { tinggi }\end{array}$ & 5 & 20,8 \\
\hline $80-89$ & Tinggi & 10 & 41,7 \\
\hline $70-79$ & Sedang & 9 & 37,5 \\
\hline $40-69$ & Rendah & 0 & 0 \\
\hline $0-39$ & $\begin{array}{c}\text { Sangat } \\
\text { Rendah }\end{array}$ & 0 & 0 \\
\hline & Jumlah & 24 & 100 \\
\hline
\end{tabular}

Pada Tabel 6 di atas menunjukkan hasil posttest siswa kelas eksperimen, ada siswa yang berada pada klasifikasi sangat tinggi yang diperoleh 5 (20,8\%) siswa. Hasil evaluasi siswa pada saat posttest berada pada skor tinggi yang diperoleh 10 siswa $(41,7 \%)$ dan klasifikasi sedang diperoleh 9 siswa (37,5\%).

Dari data di atas terlihat jelas bahwa peningkatan nilai yang diperoleh kelas eksperimen sangat signifikan karena pada pretest tidak ada siswa yang memperoleh nilai skor tinggi namun pada postest ada siswa yang memperoleh nilai sangat tinggi.
Selanjutnya akan di jelaskan peningkatan nilai siswa sebelum dan sesudah diberikan perlakuan kepada kelas eksperimen yang merupakan subyek yang diteliti. Adapun peningkatannya berdasarkan mean adalah berikut:

Tabel 7 Peningkatan Nilai Mean Kelas Eksperimen Pretest dan Posttest

\begin{tabular}{|c|c|c|c|}
\hline Kelas & Pretest & Postest & Peningkatan \\
\hline Eksperimen & 68,3 & 81 & 12,7 \\
\hline
\end{tabular}

Tabel 7 memberikan gambaran bahwa terjadi peningkatan rerata pada kelas eksperimen Peningkatan terjadi pada pada kelas eksperimen yaitu sebesar 12,7 Setelah diberi perlakuan, rerata nilai hasil belajar pada kelas eksperimen dari 68,3 menjadi 81 Artinya bahwa setelah diberikan perlakuan dengan Strategi OK5R (Overview, Key Ideals, Read, Record, Recite, Review, dan Reflect) memberikan dampak positif pada tingkat pembelajaran siswa.

\section{Peningkatan Nilai Pretest, Posttest Kelas Kontrol}

Tabel 8 Kategori,Frekuensi dan Presentase Hasil Pretest (Tes Awal)Siswa Kelas kontrol SMP Negeri 42 Bulukumba

\begin{tabular}{|c|c|c|c|}
\hline Interval & Kategori & Frekuensi & Persentase \\
\hline $90-100$ & $\begin{array}{c}\text { Sangat } \\
\text { tinggi }\end{array}$ & 0 & 0 \\
\hline $80-89$ & Tinggi & 3 & 12,5 \\
\hline $70-79$ & Sedang & 9 & 37,5 \\
\hline $40-69$ & Rendah & 12 & 50 \\
\hline $0-39$ & $\begin{array}{c}\text { Sangat } \\
\text { Rendah }\end{array}$ & 0 & 0 \\
\hline & Jumlah & 24 & 100 \\
\hline
\end{tabular}

Pada Tabel 8 di atas menunjukkan hasil pretest siswa kelas kontrol, yaitu tidak ada siswa yang berada pada klasifikasi sangat tinggi skor 90100. Hasil evaluasi siswa pada saat pretest berada pada skor tinggi yang diperoleh 3 siswa $(12,5 \%)$ dan klasifikasi sedang diperoleh 9 siswa $(37,5 \%)$ serta klasifikasi rendah diperoleh 12 siswa $(50 \%)$

\section{KESIMPULAN}

Berdasarkan penyajian data dan pembahasan dapat disimpulkan hasil tes keterampilan membaca paragraf eksposisi siswa kelas eksperimen melalui strategi OK5R 
(Overview, Key Ideals, Read, Recocd, Recite, Review dan Reflect) setelah dilakukan pada pretes dan posttest mengalami peningkatan. Sedangkan hasil tes keterampilan membaca paragraf eksposisi siswa kelas kontrol tanpa melalui strategi OK5R (Overview, Key Ideals, Read, Recocd, Recite, Review dan Reflect) setelah dilakukan pada pretes dan posttest mengalami peningkatan tapi peningkatan yang relatif sedang dibanding dengan kelas eksperimen.

Hal ini dapat dilihat dari meningkatnya skor rata-rata siswa selama penelitian ini dilakukan yaituterjadi perubahan rerata baik pada kelas eksperimen maupun kelas kontrol. Perubahan terjadi pada kelas eksperimen yaitu

\section{DAFTAR PUSTAKA}

Abdurrahman, M \& Totok Bintoro. 2000. Memahami dan Menangani Siswa dengan Problem dalam Belajar : Pedoman Guru. Jakarta : proyek Peningkatakan Mutu SLTP. Direktorat Pendidikan Menengah Umum, Direktorat jenderal Pendidikan Dasar dan Menengah, Departemen Pendidikan Nasional

Agung, A.A. Gede. 2003. Evaluasi Pendidikan. Singaraja: IKIP Negeri Singaraja.

Agung, A.A Gede. 2010. Metodologi Penelitian Pendidikan. Singaraja: Fakultas Ilmu Pendidikan Universitas Ganesha.

Ariasdi. (2008). Panduan Pengembangan Multimedia Pembelajaran. [Online]. Tersedia:http://ariasdimultimedia.wordpres s.com/2008/02/12/panduan-pengembangan-multimedia-pembelajaran.html.

Arikunto, Suharsimi. 2002. Prosedur Penelitian. Jakarta : PT. Rineka Cipta. sebesar 12,4 Setelah diberi perlakuan, rerata nilai hasil belajar pada kelas eksperimen 81 Artinya bahwa setelah diberikan perlakuan dengan Strategi OK5R (Overview, Key Ideals, Read, Record, Recite, Review, dan Reflect) memberikan dampak positif pada tingkat pembelajaran siswa. Hal ini tampak berbeda dengan rerata perubahan yang terjadi pada kelompok kontrol. Meskipun mengalami perubahan sebesar 8,7 dimana nilai rerata pretest siswa adalah 66,7 kemudian setelah diberikan posttest menjadi 75,4 namun peningkatan ini kurang membawa perbaikan dalam hasil belajar siswa. Karena masih ada siswa yang tidak konsentrasi pada saat pembelajaran.

Daryanto (2009). Penduan Proses Pembelajaran Kreatif \& Inovatif. Jakarta : AV Publisher

Dimyati dan Mujiono. (2006). Belajar dan Pembejaran. Jakarta: PT. Rineka Cipta

Sudjana. 2002. Metode Statistika. Bandung: Tarsito.

Sudjana, Nana dan Ahmad Rivai. 2006. Media Pengajaran. Bandung: Sinar Baru Algensindo.

Sugiyono, 2010. Metode penelitian pendidikan: pendekatn kuantitatif, kualitatif, dan $R \&$ $D$. Bandung: Alfabeta

Sukardi,Ph.D.2003.Metodologi Penelitian Pendidikan. Cetakan kelima. Jakarta:Bumi Aksara.

Suyanto, M. 2003.Multimedia Alat untuk Meningkatkan Keunggulan Bersaing. Andi Offset: Yogyakarta. Trianto, 2007

Wina Sanjaya. (2008). Pembelajaran dalam Implementasi Kurikulum Berbasis Kompetensi. Jakarta : Kencana Prenada Media Group. 